\title{
Pengaruh Psikologi Konsumen dan Persepsi Nilai Terhadap Minat Berinvestasi Emas Mulia Pada Pegadaian (Persero) Cabang Ulak Karang Padang
}

\author{
Oleh : \\ Faramita Rosari ${ }^{1}$, Yuni Candra ${ }^{2}$, Henny Sjafitri ${ }^{3}$ \\ ${ }^{1,2,3)}$ Fakultas Ekonomi Universitas Tamansiswa Padang \\ reiz_fhara@yahoo.co.id, yuni.candra80@gmail.com, sjafitrihenny@gmail.com
}

\begin{abstract}
Abstrak
Penelitian ini bertujuan untuk mengetahui dan menganalisis pengaruh psikologi konsumen dan persepsi nilai secara parsial dan simultan terhadap minat berinvestasi Emas Mulia pada Pegadaian (Persero) Cabang Ulak Karang Padang. Metode penelitian yang digunakan adalah kuantitatif. Teknik pengambilan sampel menggunakan, teknik purposive sampling, dengan jumlah sampel sebanyak 100 responden. Teknik analisis data yang digunakan adalah uji regresi linear berganda, uji t, uji $\mathrm{F}$ dan koefisien deteminasi. Berdasarkan hasil uji secara parsial variabel psikologi konsumen dan persepsi nilai berpengaruh signifikan terhadap minat berinvestasi Emas Mulia Pada Pegadaian (Persero) Cabang Ulak Karang Padang dengan nilai signifikan $<0,05$. hasil uji secara simultan variabel psikologi konsumen dan persepsi nilai berpengaruh signifikan terhadap minat berinvestasi Emas Mulia Pada Pegadaian (Persero) Cabang Ulak Karang Padang dengan nilai signifikan < 0,05. Dan hasil koefisien determinasi didapatkan Adjusted $R$ Square sebesar 35,9\%, sisanya $64,1 \%$ dijelaskan oleh variabel lain yang tidak dibahas dalam penelitian ini.
\end{abstract}

Kata Kunci: Psikologi Konsumen, Persepsi Nilai, dan Minat Berinvestasi.

\section{PENDAHULUAN}

\section{Latar Belakang}

Pegadaian merupakan lembaga keuangan bukan bank, di mana tugas pokoknya memberikan kredit kepada masyarakat, dengan cara khusus yaitu memakai hukum gadai. Menurut kitab Undang-undang Hukum Perdata Pasal 1150, gadai adalah hak yang diperoleh seorang yang mempunyai piutang atas suatu barang bergerak. Pegadaian (Persero) tidak hanya melayani nasabah dalam bentuk gadai saja, tetapi sudah memiliki produk yang cukup banyak seperti tempat pembayaran tagihan, investasi dalam bentuk emas mulia atau batangan, dan tabungan emas.

Investasi emas mulia yang disediakan oleh Pegadaian, berupa emas mulia batangan yang dijual kepada masyarakat secara tunai atau angsuran dengan proses mudah dan waktu yang fleksibel. Pada Tabel 1.1 dapat di lihat informasi lengkap terhadap pekembangan harga emas dari tahun 20112015 sebagai berikut: 
Tabel 1.1. Harga Emas Tahun 20112015

\begin{tabular}{|c|c|c|}
\hline No & Tahun & $\begin{array}{c}\text { Harga/Gram } \\
\text { (Rupiah) }\end{array}$ \\
\hline 1 & 2011 & Rp. 495.000 \\
\hline 2 & 2012 & Rp. 500.000 \\
\hline 3 & 2013 & Rp. 510.000 \\
\hline 4 & 2014 & Rp. 550.000 \\
\hline 5 & 2015 & Rp. 560.000 \\
\hline
\end{tabular}

Sumber: PT. Pegadaian Ulak Karang Padang, 2016

Berdasarkan Tabel 1.1 dapat disimpulkan bahwa harga emas tiap tahunnya terus mengalami peningkatan, kenaikan harga emas disebabkan karena inflasi semakin meningkat. Peningkatan harga emas, tidak hanya terjadi pada emas perhiasan saja, tetapi juga terjadi pada emas mulia yang ditawarkan oleh Pegadaian (Persero). Dengan semakin meningkatnya harga emas tersebut nasabah berminat untuk melakukan investasi karena emas mulia dapat menjadikan alternatif pilihan investasi yang aman untuk mewujudkan kebutuhan masa depan serta emas mulia banyak memberikan manfaat kepada nasabah, di mana kandungan emasnya 24 karat serta harga yang ditawarkan sangat terjangkau bagi nasabah dan untuk jangka panjang akan memiliki nilai jual yang akan terus meningkat.

Investasi emas merupakan salah satu cara menabung yang sangat baik, karena nilai jual emas, semakin lama semakin meningkat dan tingkat resiko nasabah berinvestasi tidak begitu besar, seperti kegagalan dalam berinvestasi, pencurian dan lain-lain, karena emas mulia dapat disimpan pada Pegadaian (Persero) di mana nasabah melakukan investasi. Nasabah akan termotivasi untuk melakukan investasi emas mulia, juga dipengaruhi oleh nilai jualnya yang tinggi serta kualitas emas mulia tersebut memiliki kualitas yang baik.

Disamping harga jual yang cenderung meningkat dan kualitas emas yang baik, nasabah juga mendapatkan informasi yang lengkap dari pegawai pegadaian, sehingga nasabah memahami dengan detail tentang manfaat berinvestasi dari emas mulia tersebut. Nasabah juga akan mendapatkan pembelajaran berinvestasi emas mulia karena nasabah sudah pernah melakukan investasi sebelumnya, dan dengan adanya manfaat yang diberikan dalam berinvestasi seperti memiliki harga standar, mudah dijual kembali, nilai setara dengan uang, nilai relative stabil dan cenderung naik, dan proteksi nilai uang (tidak berdampak inflasi), dengan berbagai manfaat tersebut nasabah berkeinginan kembali melakukan investasi. Selanjutnya dilihat pada emotional value nasabah, terlihat bahwa keuntungan yang diberikan kepada nasabah seperti harga yang standar dan mudah untuk dijual kembali. Berdasarkan 
uraian diatas, maka penulis tertarik untuk melakukan penelitian dan menyajikan dalam suatu karya ilmiah dengan judul: Pengaruh Psikologi Konsumen dan Persepsi Nilai Terhadap Minat Berinvestasi Emas Mulia Pada Pegadaian (Persero) Cabang Ulak Karang Padang.

\section{Rumusan Masalah}

1. Apakah psikologi konsumen berpengaruh terhadap minat berinvestasi Emas Mulia pada Pegadaian (Persero) Cabang Ulak Karang Padang?

2. Apakah persepsi nilai berpengaruh terhadap minat berinvestasi Emas Mulia pada Pegadaian (Persero) Cabang Ulak Karang Padang?

3. Apakah psikologi konsumen dan persepsi nilai secara bersamaan berpengaruh terhadap minat berinvestasi Emas Mulia Pada Pegadaian (Persero) Cabang Ulak Karang Padang?

\section{Tujuan Penelitian}

1. Untuk mengetahui dan menganalisis pengaruh psikologi konsumen terhadap minat berinvestasi Emas Mulia Pada Pegadaian (Persero) Cabang Ulak Karang Padang.
2. Untuk mengetahui dan menganalisis pengaruh persepsi nilai terhadap minat berinvestasi Emas Mulia Pada Pegadaian (Persero) Cabang Ulak Karang Padang.

3. Untuk mengetahui dan menganalisis secara bersamaan pengaruh psikologi konsumen dan persepsi nilai terhadap minat berinvestasi Emas Mulia Pada Pegadaian (Persero) Cabang Ulak Karang Padang.

\section{LANDASAN TEORI, KERANGKA} KONSEPTUAL DAN HIPOTESIS

\section{Psikologi Konsumen}

Menurut Engel et al dalam Simamora (2008:6), pada suatu saat tertentu seseorang mempunyai banyak kebutuhan baik yang bersifat biogenik maupun biologis. Kebutuhan ini timbul dari suatu keadaan fisiologis tertentu seperti rasa lapar, haus, dan sebagainya. Sedangkan kebutuhan yang bersifat pisikologis adalah kebutuhan yang timbul dari keadaan fisiologis tertentu seperti kebutuhan untuk diakui, harga diri, atau kebutuhan untuk diterima oleh lingkungannya. Menurut Kotler dan Keller (2009:166), faktor pisikologis merupakan pemilihan barang yang dibeli 
seseorang lebih lanjut dipengaruhi oleh empat faktor psikologis, yaitu motivasi, persepsi, pembelajaran dan memori.

Menurut Kotler dan Keller (2009:176), terdapat 4 (empat) proses psikologi yang dapat digunakan untuk mengukur tingkat keputusan pembelian konsumen yaitu motivasi, persepsi, pembelajaran, dan memori.

\section{Persepsi Nilai}

Menurut Kotler dan Keller (2009:228), persepsi adalah proses yang digunakan oleh individu untuk memilih, mengorganisasi, dan menginterpretasi masukan informasi guna menciptakan gambaran dunia yang memiliki arti. Nilai pelanggan merupakan kombinasi kualitas, pelayanan, harga dari suatu penawaran produk. Menurut Mahmud dalam Asanti (2015), persepsi adalah menafsirkan stimulus yang telah ada didalam otak. Persepsi merupakan pengertian kita tentang situasi kita sekarang dalam artian pengalaman- pengalaman kita yang telah lalu. Persepsi nilai (perceived value) merupakan akibat atau keuntungankeuntungan yang diterima pelanggan dalam kaitannya dengan total biaya (termasuk di dalamnya adalah harga yang dibayarkan ditambah biaya-biaya lain terkait dengan pembelian). Persepsi nilai yang dirasakan (perceived value) juga digunakan oleh konsumen untuk menimbang berbagai aspek layanan berbanding relatif dengan biaya yang ditawarkan beberapa penyedia jasa dalam persaingan.

Menurut Mahmud dalam Asanti (2015), indikator persepsi nilai (perceived value) adalah guality/performance (produk harga premium, kualitas internasional), price/value for money (harga sesuai dengan nilai produk), dan emotional value (produk sesuai karakter konsumen).

\section{Minat Beli Konsumen}

Menurut Durianto (2008), mengungkapkan bahwa niat beli timbul karena sikap, konsumen terhadap suatu objek atau produk, keyakinan konsumen pada kualitas produk, dimana semakin rendah keyakinan konsumen terhadap suatu produk maka akan semakin rendah niat beli konsumen terhadap produk tersebut.

Menurut Ferdinand (2006:129), minat digambarkan sebagai situasi seseorang sebelum melakukan tindakan yang dapat dijadikan dasar untuk memprediksi perilaku atau tindakan tersebut, minat beli merupakan sesuatu yang berhubungan dengan rencana konsumen untuk membeli produk tertentu serta berapa banyak unit produk yang 
dibutuhkan pada periode tertentu, dapat dikatakan bahwa minat beli merupakan pernyataan mental dari diri konsumen yang merefleksikan rencana pembelian sejumlah produk dengan merek tertentu. Menurut Ferdinand (2006:129), minat beli dapat diidentifikasikan melalui indikatorindikator adalah minat transaksional, minat refrensial, minat preferensial, dan minat eksploratif.

\section{Hipotesis Penelitian}

Hipotesis yang dapat penulis kemukakan dalam penelitian ini sebagai berikut:

$\mathrm{H}_{1}$ : Diduga psikologi konsumen berpengaruh signifikan terhadap minat berinvestasi Emas Mulia Pada Pegadaian (Persero) Cabang Ulak Karang Padang.

$\mathrm{H}_{2}$ : Diduga persepsi nilai berpengaruh signifikan terhadap minat berinvestasi Emas Mulia Pada Pegadaian (Persero) Cabang Ulak Karang Padang.

$\mathrm{H}_{3}$ : Diduga psikologi konsumen dan persepsi nilai secara bersama-sama berpengaruh signifikan terhadap minat berinvestasi Emas Mulia Pada Pegadaian (Persero) Cabang Ulak Karang Padang.

\section{METODE PENELITIAN}

\section{Jenis Metode Penelitian}

Metode penelitian ini adalah penelitian kuantitatif. Kuantitatif yaitu metode penelitian yang berlandaskan pada filsafat positivisme digunakan untuk meneliti pada populasi atau sampel tertentu, analisis data bersifat kuantitatif/ statistik, dengan tujuan untuk menguji hipotesis yang telah ditentukan (Sugiyono 2013:35).

\section{Definisi Operasional}

Secara teoritis, definisi operasional variabel adalah unsur penelitian yang memberikan penjelasan atau keterangan tentang variabel-variabel operasional sehingga dapat diamati atau diukur.

\section{Populasi dan Sampel Penelitian}

Populasi dalam penelitian ini adalah seluruh konsumen yang berinvstasi emas mulia pada Pegadaian (Persero) Cabang Ulak Karang Padang pada tahun 2016 yang berjumlah

139 orang konsumen. Teknik pengambilan sampel dalam penelitian ini adalah Purposive sampling, dengan kriteria 2 kali pembayaran angsuran. Jumlah sampel dalam penelitian sebanyak 100 orang responden, menggunakan rumus slovin yang dikutip oleh (Umar: 2008:107). 


\section{Teknik Pengumpulan Data}

Teknik Pengumpulan data yang dilakukan dalam penelitian ini yaitu dengan teknik observasi, angket, dan kepustakaan.

\section{Teknik Analisis Data}

Teknik analisa data yang digunakan dalam penelitian ini adalah analisis deskriptif, uji validitas, uji reliabilitas, analisis regresi berganda, uji t, uji $\mathrm{F}$ dan uji koefisien determinasi $\mathrm{R}^{2}$.

\section{HASIL PENELITIAN DAN PEMBAHASAN}

\section{Uji Regresi Linear Berganda}

Berdasarkan hasil uji regresi linear berganda dapat dilihat pada Tabel 4.1 di bawah ini:

Tabel. 4.1. Hasil Uji Regresi Linear Berganda

Coefficients $^{\mathrm{a}}$

\begin{tabular}{|c|c|c|c|c|c|}
\hline \multirow[b]{2}{*}{ Model } & \multicolumn{2}{|c|}{$\begin{array}{l}\text { Unstandardized } \\
\text { Coefficients } \\
\end{array}$} & \multirow{2}{*}{\begin{tabular}{|l|}
$\begin{array}{l}\text { Standardized } \\
\text { Coefficients }\end{array}$ \\
Beta \\
\end{tabular}} & & \\
\hline & $\mathrm{B}$ & Std. Error & & & \\
\hline (Constant) & 13.891 & 2.605 & & 5.332 & .000 \\
\hline Psikologi_Konsumen & .227 & .081 & .257 & 2.788 & .006 \\
\hline Persepsi_Nilai & .467 & .098 & 441 & 4.781 & .000 \\
\hline
\end{tabular}

a. Dependent Variable: Minat_Beli

Sumber: Data primer yang diolah, 2017

Berdasarkan hasil uji regresi linear berganda dengan menggunakan program SPSS 20 for windows, maka diperoleh hasil persamaan regresi sebagai berikut: $\mathrm{Y}=13,891+0,227 \mathrm{X}_{1}+0,467 \mathrm{X}_{2}+\mathrm{e}$
1. Nilai constanta adalah = 13,891 artinya jika tidak terjadi perubahan variabel psikologi konsumen dan persepsi nilai (nilai $\mathrm{X}_{1}$ dan $\mathrm{X}_{2}$ adalah 0) maka minat konsumen berinvestasi emas mulia pada Pegadaian (Persero) Cabang Ulak Karang

Padang tetap sebesar 13,891 satuan.

2. Nilai koefisien regresi psikologi konsumen adalah $=0,227$ artinya jika variabel psikologi konsumen $\left(\mathrm{X}_{1}\right)$ meningkat sebesar 1 (satuan) dengan asumsi variabel persepsi nilai $\left(\mathrm{X}_{2}\right)$ dan konstanta (a) adalah 0 (nol), maka minat konsumen berinvestasi emas mulia pada Pegadaian (Persero) Cabang Ulak Karang Padang meningkat sebesar 0,227 satuan.

3. Nilai koefisien regresi persepsi nilai adalah $=0,467$ artinya jika variabel persepsi nilai $\left(\mathrm{X}_{2}\right)$ meningkat sebesar 1 (satuan) dengan asumsi variabel psikologi konsumen $\left(\mathrm{X}_{1}\right)$ dan konstanta (a) adalah 0 (nol), maka minat konsumen berinvestasi emas mulia pada Pegadaian (Persero) Cabang Ulak Karang Padang meningkat sebesar 0,467 satuan. 


\section{Uji Hipotesis}

\section{Uji t}

Berdasarkan uji t dapat dilihat pada Tabel 4.2 di bawah ini:

Tabel 4.2. Hasil Uji t Coefficients ${ }^{\mathbf{a}}$

\begin{tabular}{|r|l|l|l|l|l|}
\hline \multicolumn{2}{|c|}{$\begin{array}{l}\text { Unstandardize } \\
\text { d }\end{array}$} & $\begin{array}{l}\text { Standar } \\
\text { dized }\end{array}$ & & \\
\cline { 2 - 5 } Model & B & Std. & Beta & & Sio \\
\hline (Constant) & 13.891 & 2.605 & & 5.332 & .000 \\
Psikologi_Konsumen & .227 & .081 & .257 & 2.788 & .006 \\
Persepsi_Nilai & .467 & .098 & .441 & 4.781 & .000 \\
\hline
\end{tabular}

a. Dependent Variable: Minat_Beli

Sumber : Data primer yang diolah, 2017

Berdasarkan hasil pengujian pada tabel 4.2, bisa dijelaskan sebagai berikut :

Variabel psikologi konsumen $\left(\mathrm{X}_{1}\right)$ berpengaruh secara positif dan signifikan terhadap minat konsumen berinvestasi emas mulia pada Pegadaian (Persero) Cabang Ulak Karang Padang. Hal ini terlihat dari signifikan $0,006<0,05$, dan nilai $\mathrm{t}_{\text {tabel }} \mathrm{df}=\mathrm{n}-1=100-1=99(1,660)$ berarti nilai $t_{\text {hitung }}>t_{\text {tabel }}(2,788>1,660)$, maka Ho ditolak dan $\mathrm{H}_{1}$ diterima.

\section{Variabel persepsi nilai $\left(\mathrm{X}_{2}\right)$} berpengaruh secara positif dan signifikan terhadap minat konsumen berinvestasi emas mulia pada Pegadaian (Persero) Cabang Ulak Karang Padang. Hal ini terlihat dari signifikan $0,000<0,05$, dan nilai $\mathrm{t}_{\text {tabel }} \mathrm{df}=\mathrm{n}-1=100-1=99(1.660)$ berarti nilai thitung $>$ tabel $(4,781>1,660)$ maka Ho ditolak dan $\mathrm{H}_{2}$ diterima.

\section{Uji F}

Berdasarkan uji $\mathrm{F}$ yang dilakukan secara simultan dapat dilihat pada Tabel $4.3 \mathrm{di}$ bawah ini:

\section{Tabel 4.3. Hasil Uji F} ANOVA $^{b}$

\begin{tabular}{|l|l|l|l|l|l|}
\hline & Sum of Squares & Df & Mean & F & Sig. \\
\hline 1 & 363.244 & 2 & 181.622 & 28.768 & $.000^{\mathrm{a}}$ \\
Regression & 612.396 & 97 & 6.313 & & \\
Residual & 975.640 & 99 & & & \\
\hline
\end{tabular}

a. Predictors: (Constant), Persepsi_Nilai, Psikologi_Konsumen b. Dependent Variable: Minat_Beli

Sumber : Data primer yang diolah, 2017

Berdasarkan hasil pengujian pada tabel 4.3 dapat dilihat pada nilai $F$ hitung sebesar

28,768 dengan nilai $\mathrm{F}_{\text {tabel }} d f_{1}=\mathrm{k}-1=3$ $1=2, d f_{2}=\mathrm{n}-\mathrm{k}(100-3=97)$ adalah 3,09 sehingga nilai $F_{\text {hitung }}>F_{\text {tabel }}$ atau 28,768 > 3,09, dan tingkat signifikan $0,000<0,05$ maka Ho ditolak dan $\mathrm{H}_{3}$ diterima, dapat disimpulkan bahwa variabel psikologi konsumen $\left(\mathrm{X}_{1}\right)$ dan variabel persepsi nilai $\left(\mathrm{X}_{2}\right)$ secara bersamaan berpengaruh signifikan terhadap minat konsumen berinvestasi emas mulia pada Pegadaian (Persero) Cabang Ulak Karang Padang.

\section{Uji Koefisien Determinasi}

Berdasarkan uji $\mathrm{R}^{2}$ yang dilakukan dapat dilihat pada Tabel 4.4 di bawah ini: 
Tabel 4.4. Uji Koefisien Determinasi Model Summary

\begin{tabular}{|c|c|c|c|c|c|c|c|c|}
\hline \multirow[b]{2}{*}{ Model } & \multirow[b]{2}{*}{$\mathrm{R}$} & \multirow[b]{2}{*}{$\begin{array}{c}\mathrm{R} \\
\text { Square }\end{array}$} & \multirow[b]{2}{*}{$\begin{array}{l}\text { Adjust } \\
\text { ed }\end{array}$} & \multirow[b]{2}{*}{$\begin{array}{l}\text { Std. } \\
\text { Error }\end{array}$} & \multicolumn{4}{|c|}{ Change Statistics } \\
\hline & & & & & $\begin{array}{l}\mathrm{R} \\
\text { Square }\end{array}$ & $F$ & df1 df2 & Sig. \\
\hline 1 & $.610^{\mathrm{a}}$ & .372 & .359 & 2.513 & .372 & 28.768 & 297 & .000 \\
\hline
\end{tabular}

\section{Berdasarkan tabel 4.4 dapat} diketahui bahwa nilai koefisien determinasi terdapat pada nilai Adjusted $R$ Square dengan sebesar 0,359. Hal ini berarti kemampuan variabel bebas dalam menjelaskan variabel terikat adalah sebesar $35,9 \%$ sisanya $64,1 \%$ dijelaskan oleh variabel lain yang tidak dibahas dalam penelitian ini seperti budaya (culture, sub culture, dan kelas ekonomi), sosial (kelompok acuan, keluarga serta peran status), pribadi (usia, tahapan daur hidup, pekerjaan, kedaan ekonomi, gaya hidup, serta kepribadian dan konsep diri), (Kotler dalam Kumala, 2012).

\section{Implikasi Penelitian}

1. Pengaruh Variabel Psikologi Konsumen Terhadap Minat Konsumen Berinvestasi Emas Mulia Pada Pegadaian (Persero) Cabang Ulak Karang Padang.

Minat konsumen berinvestasi emas mulia pada Pegadaian (Persero) Cabang Ulak Karang Padang dipengaruhi oleh psikologi konsumen, yaitu dengan memberikan harga purna jualnya tinggi dan memiliki kualitas yang bagus, sehingga konsumen termotivasi untuk melakukan investasi, dengan memberikan berbagai fasilitas yang menarik kepada konsumen, maka dapat mempengaruhi psikologi konsumen untuk berinvestasi emas mulia pada Pegadaian (Persero) Cabang Ulak Karang Padang. Penilaian psikologi konsumen dalam meningkatkan minat konsumen berinvestasi emas mulia pada Pegadaian (Persero) Cabang Ulak Karang Padang dapat dilihat pada nilai regresi sebesar 0,227 , dan nilai $t_{\text {hitung }}>\mathrm{t}_{\text {tabel }}(2,788>$ 1,660), hal ini terbukti bahwa psikologi konsumen berpengaruh secara positif dan signifikan terhadap minat konsumen berinvestasi emas mulia pada Pegadaian (Persero) Cabang Ulak Karang Padang.

2. Pengaruh Variabel Persepsi Nilai Terhadap Minat Konsumen Berinvestasi Emas

Mulia Pada Pegadaian (Persero) Cabang Ulak Karang Padang.

Minat konsumen berinvestasi emas mulia pada Pegadaian (Persero) Cabang Ulak Karang Padang dapat dipengaruhi oleh nilai yang dimiliki emas mulia, sehingga persepsi konsumen tentang nilai yang dimiliki emas mulia seperti harga yang standar dan mudah untuk dijual kembali, memiliki pandangan yang baik dimata konsumen sehingga minat konsumen berinvestasi emas mulia pada 
Pegadaian (Persero) Cabang Ulak Karang

Padang akan menjadi lebih meningkat, hal ini dapat dibuktikan dengan nilai regresi sebesar 0,467 dan nilai $t_{\text {hitung }}>t_{\text {tabel }}$ $(4,781>1,660)$ sehingga persepsi nilai berpengaruh secara positif dan signifikan terhadap minat konsumen berinvestasi emas mulia pada Pegadaian (Persero) Cabang Ulak Karang Padang.

3. Pengaruh Minat Konsumen Berinvestasi Emas Mulia Pada Pegadaian (Persero) Cabang Ulak Karang Padang.

Minat konsumen berinvestasi emas mulia dapat dipengaruhi oleh psikologi konsumen dan persepsi nilai yang terdapat pada diri konsumen, sehingga minat transaksional konsumen menjadi lebih meningkat serta dapat mempromosikan produk emas mulia Pegadaian kepada orang lain. Dengan terjadinya pengaruh variabel psikologi dan persepsi nilai tersebut maka dapat dilihat dari nilai $F_{\text {hitung }}$ $28,768>F_{\text {tabel }}$

3,09 sedangkan hasil Adjusted $R$ Square dengan sebesar 0,359, hal ini berarti kemampuan kedua variabel (psikologi konsumen dan persepsi nilai) menjelaskan minat konsumen berinvestasi emas mulia pada Pegadaian hanya sebesar $35,9 \%$.

\section{KESIMPULAN DAN SARAN \\ Kesimpulan}

1. Psikologi konsumen berpengaruh secara positif dan signifikan terhadap minat konsumen berinvestasi Emas Mulia Pada Pegadaian (Persero) Cabang Ulak Karang Padang dengan nilai signifikan sebesar $0,006<0,05$.

2. Persepsi nilai berpengaruh positif dan signifikan terhadap minat konsumen berinvestasi Emas Mulia Pada Pegadaian (Persero) Cabang Ulak Karang Padang, dengan nilai signifikan sebesar $0,000<0,05$.

3. Psikologi konsumen dan persepsi nilai secara bersamaan berpengaruh positif dan signifikan terhadap minat konsumen berinvestasi Emas Mulia Pada Pegadaian (Persero) Cabang Ulak Karang Padang dengan uji $F_{\text {hitung }}>$ $F_{\text {tabel }}$ atau 28,768> 3,09 dengan nilai signifikan $0,000<0,05$, sedangkan nilai adjusted $R$ Square sebesar 0,359. Hal ini berarti kemampuan variabel bebas dalam menjelaskan variabel terikat adalah sebesar $35,9 \%$ sisanya $64,1 \%$ dijelaskan oleh variabel lain yang tidak dibahas dalam penelitian.

\section{Saran}

1. Diharapkan pimpinan Pegadaian (Persero) Cabang Ulak Karang Padang lebih memperhatikan dan 
memberikan fasilitas-fasilitas yang menarik kapada konsumen dan daftar harga jual, supaya konsumen merasa nyaman pada saat bertransaksi.

2. Diharapkan pimpinan Pegadaian (Persero) Cabang Ulak Karang Padang lebih memperhatikan dan mempertahankan kualitas emas yang dimiliki serta menawarkan harga yang terjangkau, supaya calon konsumen kalangan menegah kebawah dapat berinvestasi emas mulia pada Pegadaian (Persero) Cabang Ulak Karang Padang.

3. Bagi peneliti selanjutnya penulis menyarankan agar memperbanyak jumlah responden yang akan digunakan serta dilakukan dengan rentang waktu yang lebih lama. Hal ini perlu dilakukan agar hasil yang ditemukan dalam penelitian tersebut akan lebih baik dari penelitian ini.

\section{DAFTAR PUSTAKA}

Asanti Amalia Mahdhiani 2015. Pengaruh Electronik Word Of Mounth dan Persepsi Nilai Terhadap Minat Bowl-Ling Fruit Bar di Yogyakarta.

Durianto, Darmadi. dkk. 2008. Brand Equity Ten, Strategi Memimpin Pasar. Jakarta: Gramedia Pustaka Utama.

Ferdinand, Augusty. 2006. Pengembangan Minat Beli Merek Ekstensi. Semarang: Badan Penerbit Universitas. Diponegoro.

Kotler, Philip dan Kevin Lane Keller. 2009. Manjaemen Pemasaran. Diterjemahkan oleh Bob Sabran M.M. Edisi Ketiga Belas. Jilid 1. Jakarta: Erlangga.

Simamora, B. 2008. Riset Pemasaran : Falsafah, Teori, dan Aplikasi. Jakarta : Gramedia Pustaka Utama.

Sugiyono. 2013. Metode Penelitian Bisnis (Pendekatan Kuantitatif, Kualitatif, dan R\&D). Bandung: Alfabeta. 